\title{
CADMIUM BIOACCUMULATION AND ITS EFFECTS ON SOME HEMATOLOGICAL AND HISTOLOGICAL ASPECTS IN CARP, CYPRINUS CARPIO L., AT SELECTED TEMPERATURE
}

\section{BIOAKUMULACJA KADMU W KARPIU, CYPRINUS CARPIO L. PRZY WYBRANEJ TEMPERATURZE ORAZ JEJ WPL YW NA ZMIANY HEMATOLOGICZNE I HISTOLOGICZNE}

\author{
Institute of Ich thyology, Academy of Agriculture, \\ Szczecin
}

\begin{abstract}
Cadmium bioaccumulation and its effects on the changes of some hematological parameters in carp, Cyprinus carpio L., was studied. Carp was exposed $24 \mathrm{hr}$ to acute concentration of cadmium ( $0.5 \mathrm{mg} \mathrm{Cd} / \mathrm{dm}^{3}$ water) at $27^{\circ} \mathrm{C}$. Particularly the greatest accumulation of cadmium was in gills, kidneys, alimentary canal, hepatopancreas, and with lesser degree in spleen and vertebral column; while in skin and muscles accumulated only low levels of cadmium. Hematologically, cadmium bioaccumulation significantly rised erythrocytes count, hemoglobin content, hematocrite value and blood glucose, but decreased leukocytes count in comparison to control samples. Histologically, cadmium caused pathological alterations in the gill filaments and respiratory lamellae, hepatopancreas and kidney but did not affecting the skin. In addition, cadmium disturbed the metal contents $(\mathrm{Cu}, \mathrm{ZN}, \mathrm{Fe}$ and $\mathrm{Mg})$ in organs in which it accumulated.
\end{abstract}

\section{INTRODUCTION}

Anthropogenic contamination of the aquatic environment by cadmium has increased substantially in the last several decades and resulted in the elevation of $\mathrm{Cd}$ in the tissues of aquatic organisms at all trophic levels. Although acute toxically testes are used to safe concentration of toxicants in the environment, they provide little informations on the 
mode of toxic action or environmental situations where accessory factors affect toxicity. By combining physiological and histological studies with more traditional acute toxicity test one can gain insight into the mode and site of toxic action, as well as determine environmentally safe concentrations of toxicants. Cadmium is highly able to accumulated in the living organisms. In fish, the gill, kidney, alimentary cana, and liver are the primary target organs for cadmium (Rowe and Massaro, 1974; Sangalang and Freeman, 1979; Giles, 1988). Due to its ability to accumulated in organs, several pathobiochemical and histological alterations appeared (Axelson and Piscator, 1966; Gardner and Xevich, 1970; Giles and Pant, 1983; Lowe-Linde and Niimi, 1984; Donald and Giesy, 1986). Many of the observed toxic effects of cadmium are though to be the results of induced secondary deficiencies in such essential trace elements as copper, iron and zinc, since the uptake of cadmium both antagonizes and antagonized by the uptake of these metals (Bremner, 1974). Cadmium induced disturbance in copper, iron and zinc in organs that accumulated it (Stonard and Webb, 1976; Ashby et al., 1980). The present study was conducted to compare the results of histopathological and hematological diagnostis procedures relative to elucidating the mode and sites of cadmium accumulation and toxicity in carp., Cyprinus carpio L., that exposed to cadmium.

\section{MATERIALS AND METHODS}

Healthy carp, Cyprinus carpio L., was collected from Fish Farming Station at Nowe Czarnowo in Poland. Fishes were acclimized in the laboratory three weeks at $19^{\circ} \mathrm{C}$ in a large well-aired aquaria. Fish average weight was $450 \mp 50$ gramms. The sample size for each experiment was four fishes. Fishes were divided into two groups, the first one (control) kept in cadmium free water at $27^{\circ} \mathrm{C}$, while the second group exposed $24 \mathrm{hr}$ to acute concentration of cadmium in water $\left(0.5 \mathrm{mg} \mathrm{Cd} / \mathrm{dm}^{3}\right.$ water $)$ at $27^{\circ} \mathrm{C}$. After the exposure period, fish samples were removed from the aquaria. Blood was collected from the caudal vessel by means of heparinized cold syringe (Johanson-Sjobeck and Larsson, 1978), fishes were killed and dissected quickly to extract gills, kidneys, alimentary canal, muscles, hepatopancreas, spleen, vertebral column, and skin for bioaccumulation and histological studies.

HEMATOLOGICAL ANALYSIS: Erythrocyte count was determined by spectrophotometric method; while leukocyte count was determined by mixing method and counting took place by Thoma-slide. Hemoglobin concentration was determined by cyanmethemoglobin method (Wintrobe, 1956) using Drabkin's reagent. Hematocrite value was determined by using heparinized microhematocrite tubes that filled with blood samples and sealed on one end, then centrifuged 15 minutes at 11000 r.p.m in microhematocrite centrifuge, and the ratio of erythrocytes to plasma in percents was measured with an hematocrite reader. Blood indices were computed from $\mathrm{Hb}, \mathrm{Ht}$ values and erythrocytes count: 


$$
\begin{aligned}
& \operatorname{MCHC}(\%)=\frac{\mathrm{Hb}(\mathrm{gm} / 100 \mathrm{ml} \text { blood }) \times 100}{\mathrm{Ht}(\%)} \\
& \operatorname{MCH}(\mathrm{pg})=\frac{\mathrm{Hb}(\mathrm{mg} / 100 \mathrm{ml} \text { blood }) \times 10}{\mathrm{RBC} \text { in millions } / \mathrm{ml} \text { blood }} \\
& \operatorname{MCV}\left(\mu \mathrm{m}^{3}\right)=\frac{\mathrm{Ht}(\%)}{\mathrm{RBC} \text { in millions } / \mathrm{ml} \text { blood }}
\end{aligned}
$$

blood glucose was determined by o-toluidine method.

HISTOLOGICAL STUDIES, were done by manual routine method and staining was in hematoxylin and eosin.

CHEMICAL ANALYSIS. Cadmium and other metals $(\mathrm{Cu}, \mathrm{Fe}, \mathrm{Zn}$, and $\mathrm{Mg}$ ) were determined by atomic absorption spectrophotometric metod after complete oxidation by a mixture of $\mathrm{HNO}_{3}+\mathrm{HClO}_{4}$ (4:1) (Protasowicki, 1985). The elements concentration were represented in $\mu \mathrm{g} / \mathrm{g}$ wet organ. Statistically, data were analysed by F-test for variance and Student's t-test or Welch's and Aspin's test at 0.01 and 0.05 level of significance.

\section{RESULTS AND DISCUSSION}

$\mathrm{Cd}, \mathrm{Cu}, \mathrm{Zn}$, and $\mathrm{Mg}$ concentrations in different organs of carp following acute exposure to $\mathrm{Cd}$ are listed in table (1). Gills, kidneys, alimentary canal, and hepatopancreas accumulated the greatest amount of $\mathrm{Cd}$, but spleen and vertebral column accumulated a lesser degree, as well as muscle and skin accumulated only very low levels of $\mathrm{Cd}$ in comparison to control samples. Cadmium is selectively localized in tissues and the investigations designed here to determine the fate of $\mathrm{Cd}$ in the body of carp after exposure to cadmium indicated that the metal is normally accumulated in the following order: gill $>$ kidneys $>$ alimentary canal $>$ hepatopancreas $>$ remainder of the body $>$ the muscle. This selectivity was similarly mentioned in previous studies. In present study, muscle and skin accumulated only low levels of cadmium supporting other observations of other (Sangalang and Freeman, 1979; Wilson et al., 1981; Giles 1988; Protasowicki and Chodyniecki, 1988) species' of fresh water fishes.

EFFECT OF CADMIUM ON 'TRACE METALS: In present study there is no significance correlation between cadmium and other metals after the exposure to cadmium, but there is a significant differences in comparison to control samples.

Copper increased in skin, ileum, and liver, but decreased in gills, muscle, and vertebral column. These results are parallel to data reported by some authors who suggested that $\mathrm{Cd}$ may disturb $\mathrm{Cu}$ metabolism by inhibiting the biliary excretion of $\mathrm{Cu}$ resulting in 
Cadmium, copper, zinc, iron, and magnesium concentrations in organs of carp ( $\mu \mathrm{g} / \mathrm{g}$ wet organ)

Table

\begin{tabular}{|c|c|c|c|c|c|c|}
\hline \multicolumn{2}{|c|}{ Organs } & $\mathrm{Cd}$ & $\mathrm{Cu}$ & $\mathrm{Zn}$ & $\mathrm{Fe}$ & $\mathrm{Mg}$ \\
\hline Gill & $\begin{array}{l}\mathrm{C} \\
\mathrm{T}\end{array}$ & $\begin{array}{l}0.213 \pm 0.009 \\
7.229 \pm 4.048 * *\end{array}$ & $\begin{array}{l}1.06 \pm 0.08 \\
0.72 \pm 0.20^{*}\end{array}$ & $\begin{array}{l}333.1 \pm 50.7 \\
34.8 \pm 3.50^{* *}\end{array}$ & $\begin{array}{l}143.4 \pm 11.5 \\
142.8 \pm 26.4\end{array}$ & $\begin{array}{l}517.1 \pm 16.6 \\
446.1 \pm 14.5\end{array}$ \\
\hline \multirow[t]{2}{*}{$\mathrm{HP}$} & $\mathrm{C}$ & $0.330 \pm 0.029$ & $16.43 \pm 9.6$ & $209.4 \pm 69.0$ & $174.3 \pm 27.8$ & $280.3 \pm 95.2$ \\
\hline & $\mathrm{T}$ & $0.711 \pm 0.011^{* *}$ & $37.41 \pm 2.9 *$ & $35.3 \pm 20.2 * *$ & $87.4 \pm 14 * *$ & $257.7 \pm 56.1$ \\
\hline \multirow[t]{2}{*}{ Kid. } & $\mathrm{C}$ & $0.709 \pm 0.267$ & $1: 42 \pm 0.19$ & $917.5 \pm 56.3$ & $113.5 \pm 48.2$ & $201.8 \pm 50.7$ \\
\hline & $\mathrm{T}$ & $1.738 \pm 0.314 * *$ & $1.70 \pm 0.22$ & $272.4 \pm 25.6^{*}$ & $118.6 \pm 10.8$ & $211.8 \pm 47.8$ \\
\hline \multirow[t]{2}{*}{ AC. } & $\mathrm{C}$ & $0.548 \pm 0.106$ & $1.79 \pm 0.05$ & $454.5 \pm 17.8$ & $16.3 \pm 3$ & $247.5 \pm 48.1$ \\
\hline & $\mathrm{T}$ & $1.048 \pm 0.150 * *$ & $8.21 \pm 1.69 * *$ & $409.7 \pm 13.7$ & $72.3 \pm 15.7^{*}$ & $404.2 \pm 45.9 *$ \\
\hline \multirow[t]{2}{*}{ Sp. } & $\mathrm{C}$ & $0.214 \pm 0.053$ & $3.12 \pm 1.73$ & $153.4 \pm 12.7$ & $163.6 \pm 15.6$ & $267.3 \pm 30.5$ \\
\hline & $\mathrm{T}$ & $0.306 \pm 0.007 * *$ & $1.13 \pm 0.14 *$ & $195.0 \pm 6 * *$ & $233.7 \pm 20.8$ & $254.1 \pm 15$ \\
\hline \multirow[t]{2}{*}{ VC. } & C & $0.230 \pm 0.083$ & $1.59 \pm 0.19$ & $70.12 \pm 3.4$ & $011.9 \pm 0.8$ & $999.9 \pm 39.9$ \\
\hline & $\mathrm{T}$ & $0.575 \pm 0.291$ & $0.78 \pm 0.14$ & $54.59 \pm 10.9 *$ & $36.0 \pm 12 * *$ & $918.6 \pm 42.2$ \\
\hline \multirow[t]{2}{*}{ Skin } & $\mathrm{C}$ & $0.047 \pm 0.004$ & $0.48 \pm 0.08$ & $118.5 \pm 24.6$ & $13.82 \pm 2.6$ & $115.7 \pm 12.7$ \\
\hline & $\mathrm{T}$ & $0.060 \pm 0.008^{*}$ & $0.74 \pm 0.04 * *$ & $51.6 \pm 11.0 * *$ & $7.98 \pm 0.8^{*}$ & $148.5 \pm 21.5^{*}$ \\
\hline \multirow[t]{2}{*}{ Mus. } & $\mathrm{C}$ & $0.049 \pm 0.011$ & $0.32 \pm 0.02$ & $8.48 \pm 1.700$ & $3.83 \pm 0.7$ & $344 \quad \pm 32.4$ \\
\hline & $\mathrm{T}$ & $0.051 \pm 0.009$ & $0.25 \pm 0.04 *$ & $3.89 \pm 0.210 * *$ & $6.19 \pm 0.8^{*}$ & $773.8 \pm 65.6^{* *}$ \\
\hline
\end{tabular}

Note, each value represents the mean concentration in organs $(\mu \mathrm{g} / \mathrm{g})$ wet organ) $\pm \mathrm{SD}$. Asterisks denote significance differences between test' and control groups; $* \mathrm{P}<0.05$ and $* * \mathbb{P}<0.01$. (C) denotes control samples; and (T) the toxicated. HP (hepatopancreas), AC (alimentary canal), Kid. (kidney), Sp. (spleen), VC. (vertebral column), Mus. (muscles). 
accumulation of liver copper which stimulates ceruloplasmin synthesis. Since one function of ceruloplasmin is a copper donor to extrahepatic tissues (Owen, 1965).

Iron is decreased significantly in liver and skin, while increased in ileum, muscle and vertebral column. The disturbance in $\mathrm{Fe}$ concentrations after exposue to acute $\mathrm{Cd}$ conc. suggested that $\mathrm{Cd}$ also interfers with $\mathrm{Fe}$ metabolism. The decreased in hepatic Fe may be due to increased the lost of $\mathrm{Fe}$ as ferritin in the process of erythropeiosis to increase $\mathrm{RBC}$ production, as supported in present results (table 2), and that confirmed by Stonard and Webb (1976) who - reported that diminished ferritin iron in liver after cadmium administration. Zinc was decreased markdely in all organs; and that may be due to increase $\mathrm{Zn}$ excretion in bile. Magnesium, in present results, was not affected significantly, except in ileum, muscle, and skin $\mathrm{Mg}$ increased significantly, i.e. $\mathrm{Cd}$ is synergtic to magnesium absorption in ileum.

HISTOPATHOLOGY: Gross examination revealed that gill filaments were thicker three to four times the size of those in controls. No other significant gross pathology was obvious. Microscopic examinations, stricking histopathology was observed in gill filaments and respiratory lamellae, kidney, and hepatoparıcreas of carp after cadmium exposure.

Gill filaments and respiratory lamellae: Alterations of gill filaments and respiratory lamellae were represented in figure $1 \mathrm{~b}$. Microscopic examination revealed hypertrophy of gill filaments, and hyperplasia of the-epithelial surface of respiratory lamellae and interlamellar filament epithelium. The hyperplasia was accompanied by a marked increase of mitotic figures, and the lamellae fused together and appeared as club-shaped lamellae. Necrotic and sloughed respiratory epithelium was observed. Our present observations are parallel to opinion of some authors that suggested respiratory system of teleost may be damage by cadmium, since acute concentration of cadmium was found to cauterize the gill lamellae of several fresh water fishes (Karlsson et al., 1985). In the instance of necrotized gill epithelium, the underlying basal cells were also destroyed. The impairment of these cells, from which the gill epithelium generates, might essentially nullify external activity of the gills. Further, the respiratory and external functions of the gill would appear to be impaired, following hypertrophy and hyperplasia of the internal epithelia, by more reduction of the respiratory surface in comparison to control (fig. 1a).

Kidneys: The damage appeared limited to the proximal tubules of the kidney after exposure to $\mathrm{Cd}$ (figure $2 \mathrm{~b}$ ) in comparison to controls (figure 2a). Many of the proximal tubules exhibited pink - staining granules casts with nuclear debris, as well as cloudy swelling and hypertrophy of proximal tubules epithelial cells. The investigations designed to determine the fate of $\mathrm{Cd}$ in he body indicated that $\mathrm{Cd}$ is normally accumulated in the proximal tubules of kidney, where renal damage is considered to appear first in the case of intoxication (Axelsson and Piscator, 1966; Protasowicki and 'Morsy, in press). .

Hepatopancreas: The alterations in hepatopancreas, due to cadmium exposure, were represented in the damage, atrophy, and necrosis of hepatic cells that decreased in size, and their outline became indistingushable, and their nuclei and nucleoli_became small in size (figure $3 b$ ) in comparison to controls (figure $3 a$ ). 

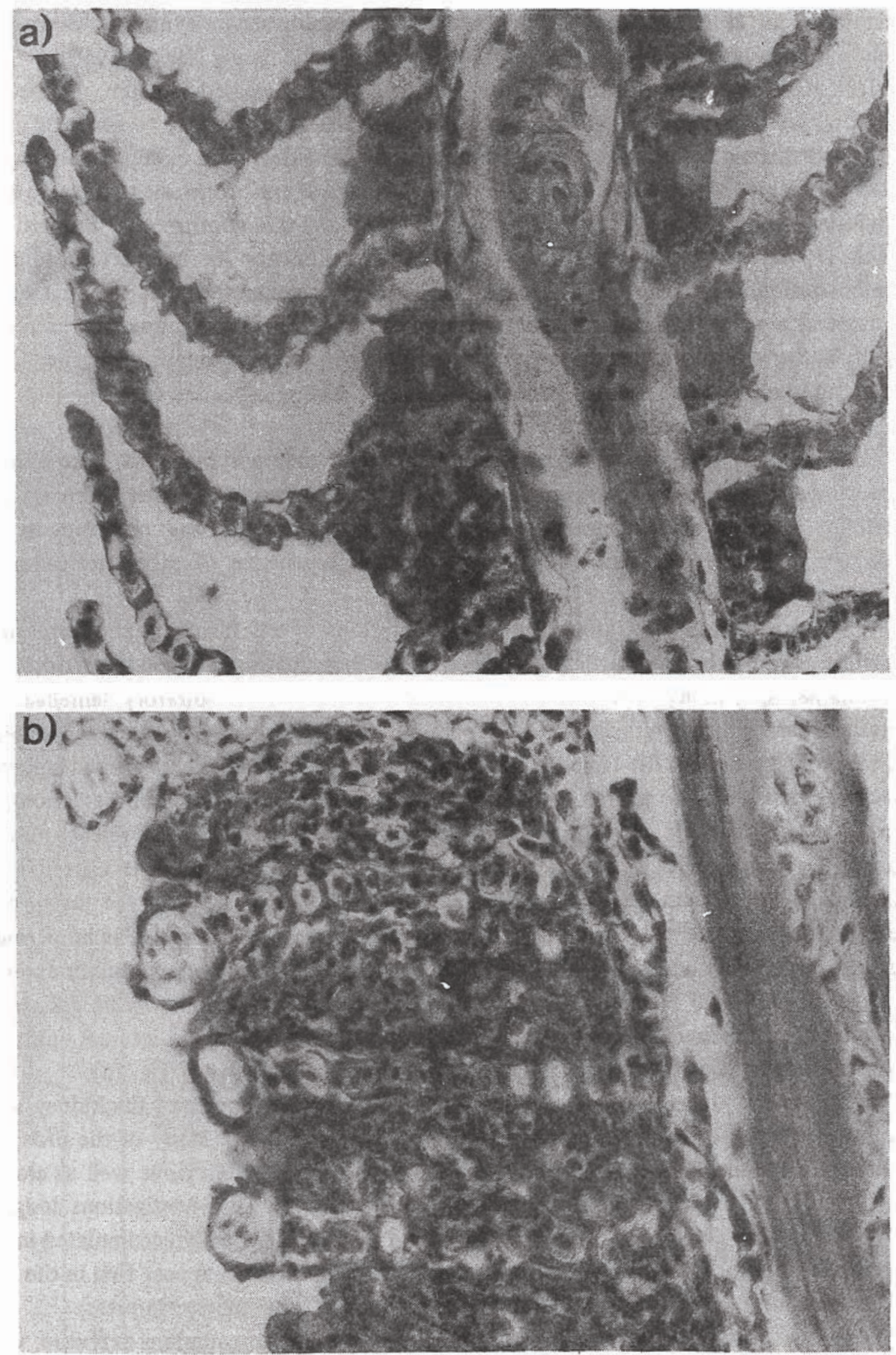

Fig. 1. Gill filaments, (a) represents the ty pical structure; while (b) indicates the toxic effect of cadmium (x1000) 

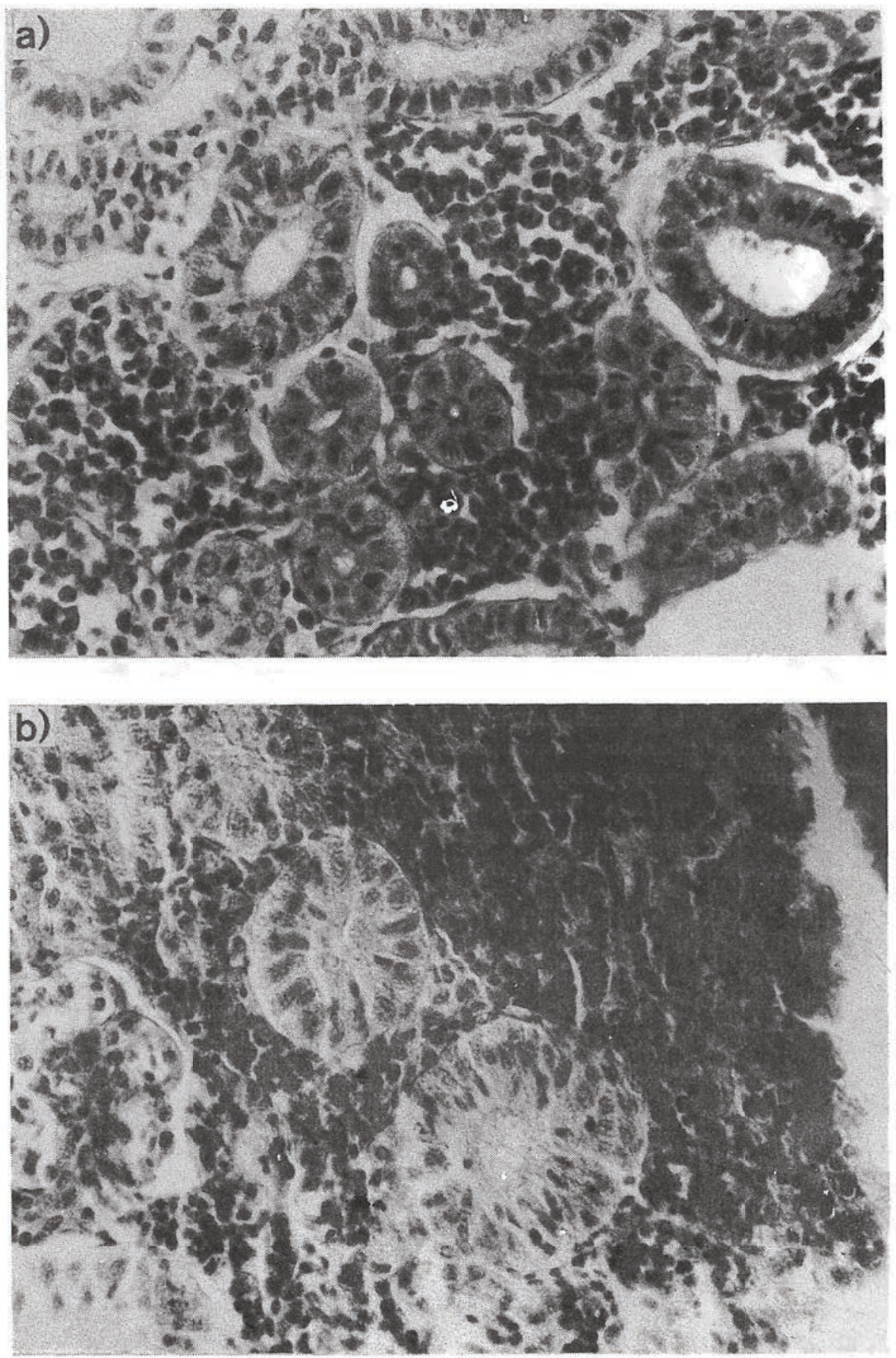

Fig. 2. Kidney, (a) represents normal architecture, whereas;

b) show cadmium induced damage to renal tubules after $24 \mathrm{hr}$ of exposure (x945) 

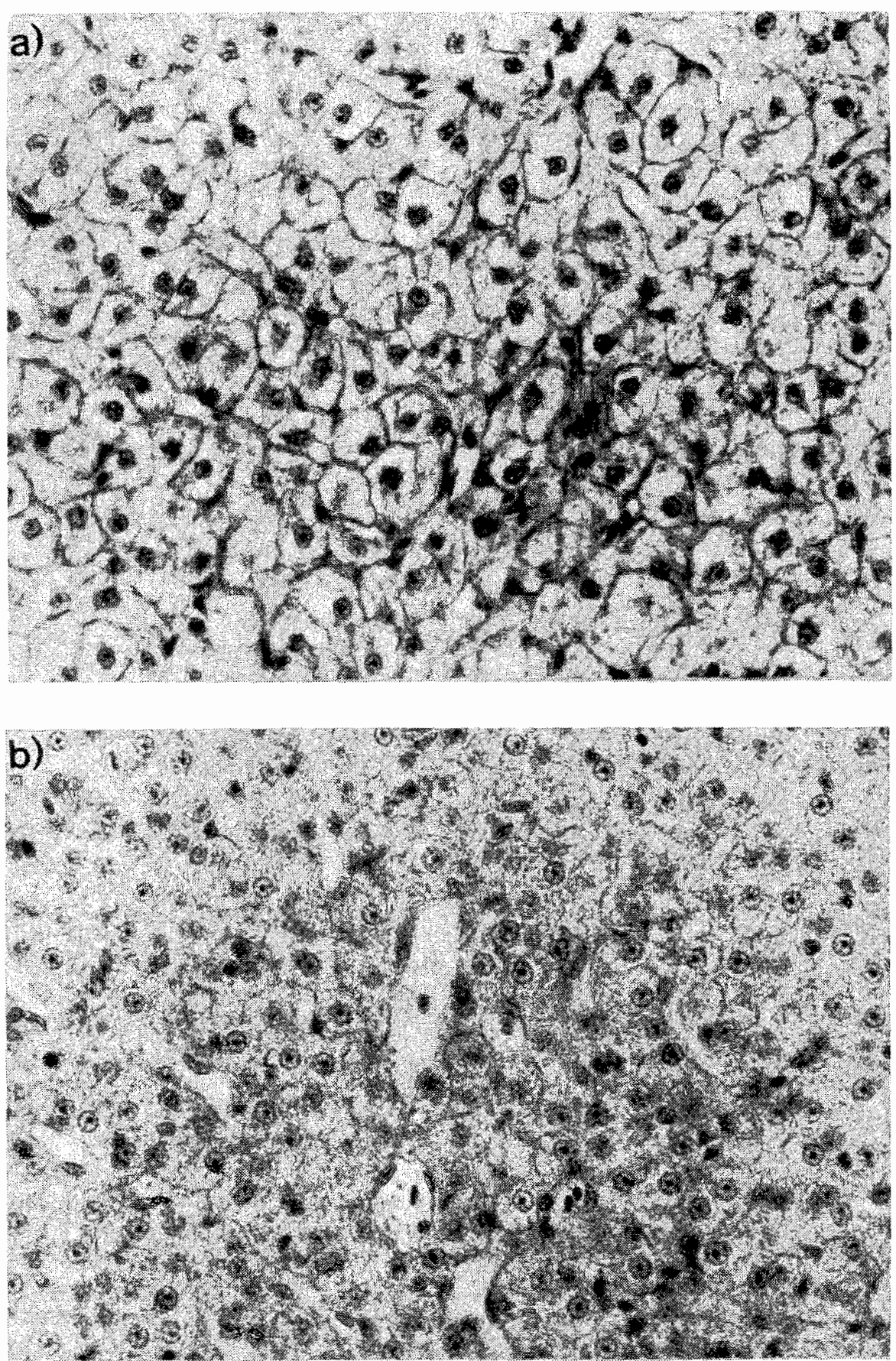

Fig. 3. Liver (a) represents the typical appearance of the hepatic celts, while (b) indicates stage of cadmium effect (x630) 
RBCC, Hb, Ht, MCHC, MCH, MCV, WBCC, and blood glucose of carp af ter exposure to cadmium $(\mathrm{T})$, and the controls $(\mathrm{C})$

\begin{tabular}{|c|c|c|c|c|c|c|c|c|}
\hline & $\mathrm{RBCC}$ & $\mathrm{Hb}$ & $\mathrm{Ht}$ & MCHC & $\mathrm{MCH}$ & $\mathrm{MCV}$ & WBCC & Glucose \\
\hline $\mathrm{C}$ & $2.36 \mp .04$ & $10.8 \mp .4$ & $42.0 \mp 1.0$ & $26 \mp .28$ & $44 \mp 4.6$ & $183 \mp 1.8$ & $9.4 \mp .7$ & $57.5 \mp 8$ \\
\hline $\mathrm{T}$ & $2.74 \mp .20 * *$ & $12.2 \mp .4^{* *}$ & $47.0 \mp 2.0 * *$ & $26 \mp .33$ & $44 \mp 4.9$ & $181 \mp 1.9$ & $4.5 \mp .7 * *$ & $143 \mp 30 * *$ \\
\hline
\end{tabular}

Each value represents the mean of four fishes $\mp \mathrm{SD}_{\bullet}$ Asterisks denote differences between test' and control groups: $* \mathrm{P}<0.05$ and $* * \mathrm{P}<0.01$. 
Skin: There was no histological changes for skin after exposure to cadmium, and that may be due to low level of $\mathrm{Cd}$ accumulated by the skin that increased the mucous secretion during exposure period, and that fixed $\mathrm{Cd}$ on the surface as a protection against toxicants.

HEMATOLOGICAL EFFECT: RBCC, $\mathrm{Hb}, \mathrm{Ht}$, and blood glucose were increased significantly, while leukocytes decreased; but did not caused any statistical significance for $\mathrm{MCHC}, \mathrm{MCH}$, and $\mathrm{MCV}$ after exposure to $\mathrm{Cd}$, in comparison to controle (table 2). The increased $\mathrm{RBCs}, \mathrm{Ht}$, and $\mathrm{Hb}$ may be as indirect effect of cadmium on gills, since as observed above, $\mathrm{Cd}$ impairment in respiration and increased oxygen consumption (Bishope and Alan, 1981) due to gill destroying, and this caused shortage in oxygen supply for fish. Oxygen shortage acts as activating factor for $\mathrm{RBCs}$ and $\mathrm{Hb}$ production to capture more amount of oxygen (Wagh et al., 1985). Hyperglycemia may be due to alternations in physiological functions of $\alpha$ - and $\beta$-cells in Islet's of Langerhans as a result of $\mathrm{Cd}$ accumulation in hepatopancreas, and that caused disturbance in blood glucose level (Giles and Pant, 1983).

\section{CONCLUSION}

We have been detected cadmium - induced damagae of tissues during acute exposure which to be able to produce histopathological effects on the internal organs that accumulated a greatest amount of cadmium, and this caused some hematological alternations in carp, i.e. it is possible to combining histological and hematological alternations to indicate the site and mode of acute cadmium toxicity. In addition, acute exposure to cadmium significantly alter the tissue disposition of other elements; but the mechanism by which cadmium exerts its influences on other metals are not, as yet, fully understood.

\section{REFERENCES}

Ashby S.L., L.J. King, D.V. Parke, 1980: Effect of acute administration of cadmium on the deposition of copper, zinc., and iron in the rat. Environ. Res., 21: 177-185.

Exelsson B., M. Piscator, 1966: Renal damage after prolonged exposure to cadmium. Arch. Environ. Health, 12: 360-373.

Bishop E.W., W.M. Alan, 1981: Acute lethality and effects of cadmium exposure on ventilation frequency and cough rate of bluegill. Lepomis macrochirus. Arch. Envron. Cont. Toxicol., 105 : 519-530.

Bremner I., 1974: Heavy metàl toxicity. Quart. Rev. Biophys., 7: 75-124.

Donald J.V., J.P. Giesy, 1986: The histological and biochemical effects of cadmium exposure in the blue gill sunfish, Lepomis macrochirus. Ecotoxicol. Environ. Saf., 11: 31-43. 
Gardner G.R., P.P. Xevich, 1970: Histological and hematological responses of an esturiane teleost to cadmium. J. Fish. Res. Bd Canada, 27: 2185-2195.

Giles M.A., 1988: Accumulation of cadmium by rainbow trout, Salmo gairdneri, during extended exposure. Can. J. Fish. Aquatic. Sci., 45: 1045-1053.

Giles T.S., J.C. Pant, 1983: Cadmium toxicity: Inducement of changes in blood tissue metabolites of fish. Toxicol. Lett., 18: 195-200.

Johansson-Sjobeck M.L., A. Larsson, 1978: The effect of cadmium on the hematology and on the activity of $\delta$-ALAD in blood and hematopoietic tissues of flounder, Platichthys flesus. Environ. Res., 17: 191-204.

Karlsson L.,P.Runn, C. Haux, L. Forlin, 1985: Cadmium-induced changes in morphology of zebrafish, Brachydanio rerio, and rainbow trout, Salmo gairdneri. J. Fish. Biol., 27: 81-95.

Lowe-Linde L., A.J. Niimi, 1984: Hematological characteristics of Rainbow trout. Salmo gairdneri, in response to cadmium exposure. Bull. Environ. Cont. Toxicol., 37: 375-384.

Owen C.A., 1965: Metabolism of radiocopper in the rat. Amer. J. Physiol., 209: 900-904.

Protasowicki M, 1985: Comparison of techniques of fish sample preparation for heavy metals analysis by flame AAS. Proc. 24 thCSI, Garmisch - Partenkirchen 15-20.09.1985, 3Th I 046: 548-549.

Protasowicki M., A. Chodyniecki, 1988: Bioakumulacja Cd, Pb, Cu i Zn w karpiu - Cyprinus carpio L. w zależności od stężenia w wodzie i czasu ekspozycji. Zesz. Nauk. AR Szczec., 133:69-84 (in Pollish).

Protasowicki M., G. Morsy: Gistologiceskje izmiennienja v organach ryb, kak rezultat bioakkumulacji kadmija. [in Russian]. In press.

Rowe D.W., E.J. Massaro, 1974: Cadmium uptake and time dependent alternations in tissue levels in the white catfish, Ictalurus catus. Bull. Environ. Contam, Toxicol., 11: 244-249.

Sangalang G.B., H.C. Freeman, 1979: Tissue uptake of cadmium in brook trout, during choronic sublethal exposure. Arch. Environ. Contam. Toxicol., 8: 77-84.

Stonard M.D., M. Webb, 1976: Influence of dietary cadmium on the distribution of the essential metals copper, zinc, and iron in tissues of rat. Chem. Biol. Interactions, 15: 349-363.

Wagh S.B., K. Shareef, S. Shaikh, 1985: Acute toxicity of cadmium sulphate, zinc sulphate, and copper sulphate to Barbus ticto; Effect on oxygen consumption and gill histology. J. Environ. Biol., 16 4: 287-293.

Wilson D., B. Finlayson, N. Morgan, 1981: Copper, zin, and cadmium concentrations of resident trout related to acid-mine westes. Calif. Fish Game, 67: 176-186.

Wintrobe M.M., 1956: Clinical hematology $4^{\text {th }}$ ed. Lea and Febiger, Philadelphia.

\section{Mohamed Gamal Morsy, Mikołaj Protasowicki}

\section{BIOAKUMULACJA KADMU W KARPIU - CYPRINUS CARPIO L. PRZY WYBRANEJ TEMPERATURZE ORAZ JEJ WPE YW NA ZMIANY HEMATOLOGICZNE I HISTOLOGICZNE}

\section{STRESZCZENIE}

Badano bioakumulację kadmu i jej wpływ na zmiany niektórych parametrów hematologicznych oraz histologicznych u karpia - Cyprinus carpio L. Karpie eksponowano na wysokie stężenie kadmu $\left(0,5 \mathrm{mg} \mathrm{Cd} / \mathrm{dm}^{3}\right.$ wody) przez $24 \mathrm{godz}$. w temperaturze $27^{\circ} \mathrm{C}$. Najwyższa akumulacja kadmu miała miejsœe w skrzelach, nerkach, przewodzie pokarmowym i wątrobotrzustce. W mniejszym stopniu kumulowały ten pierwiastek śledziona i kości kręgosłupa. Natomiast w skórze i mięśniach jego zawartość była najmniejsza. 
Bioakumulacja kadmu w porównaniu z próbą kontrolną powodowała istotny wzrost liczby erytrocytów, zawartości hemoglobiny, hematokrytu i poziomu glukozy we krwi przy równoczesnym spadku liczby leukocytów.

W obrazie histologicznym, u ryb poddanych intoksykacji, kadm powodował patologiczne zmiany w listkach skrzelowych, wątrobotrzustce i nerkach, przy braku widocznych zmian w skórze.

Ponadto kadm powodował zaburzenia poziomu innych metali $(\mathrm{Cu}, \mathrm{Zn}, \mathrm{Fe}$ i $\mathrm{Mg})$ w narządach w których odkładał się w znacznych ilościach.

Author's address:

Received: 1990.02 .20

Doc. dr hab. Mikołaj Protasowicki, mgr Mohamed Gamal Morsy

Akademia Rolnicza, Instytut Ichtiologii

ul. Kazimierza Królewicza 4

71-550 Szczecin, Polska (Poland) 